\title{
'N SALUUT AAN DIE REKTOR VAN DIE P.U. VIR C.H.O.
}

As die universiteit vanaf die vroegste tye die gemeenskap-in-klein genoem is, is die rektor van 'n moderne universiteit sekerlik die mikrokosmos van die universiteit waaraan hy verbonde is. Van hom word die gevleuelde idealisme van die akademikus asook die barre realisme van die administrateur verwag; hy moet 'n profetiese visie op die lonkende horison van beginsels en ontwikkelingspotensialiteit rig, maar tog met albei voete op die vaste aarde van materiaal tot sy beskikking en doeltreffende organisasie bly staan. Hy moet weet wat hy wil, maar ook wat hy kan.

Hierdie buitengewone eienskappe het sy kollegas en vriende reeds lankal in prof. Bingle gesien, maar wie nou rustig lees wat in die intreerede van die nuwe Rektor van die P.U. vir C.H.O. staan, sal saamstem dat 'n universiteit gelukkig gereken kan word om as opvolger van drie groot voorgangers weer eens ' $n$ man van formaat ter beskikking te hê.

In genoemde intreerede stel prof. Bingle die ideaal van 'n universiteit met 'n eie karakter, tradisie en cachet, nl. die Christelike en volkseie, maar tog terselfdertyd gerig op die behoeftes van die gemeenskap van die tyd waarin ons leef, d.w.s. 'n moderne universiteit. Alle ondersteuners van die P.U. vir C.H.O. verheug hulle oor die volgende gestaalde woorde en ondubbelsinnige verklaring: „Daar mag dus nie gerus word met die P.U. vir C.H.O. voordat al die basiese fakulteite hier ingestel is en al die relevante basiese beroepe aangebied word nie".

Die Redaksie en Direksie van „Koers” wil prof. Bingle geluk wens met die rektoraat en hom verseker van die beste wense op sukses en arbeidsgenot. Die grond van ons optimisme en vertroue is die wete dat die Rektor die Christelike Kragbron ken.

W. N. Coetzee. 
